\title{
Climate evolution during the Pleniglacial and Late Glacial as recorded in quartz grain morphoscopy of fluvial to aeolian successions of the European Sand Belt
}

\author{
Barbara Woronko ${ }^{1^{*}}$, Paweł Zieliński², Robert Jan Sokołowski ${ }^{3}$ \\ ${ }^{1}$ Faculty of Geology, University of Warsaw, Al. Żwirki i Wigury 93, 02-089 Warsaw, Poland; bworonko@uw.edu.pl \\ ${ }^{2}$ Department of Geoecology and Palaeogeography, Maria Curie-Skłodowska University in Lublin, Kraśnicka 2cd, \\ 20-718 Lublin, Poland; pziel@umcs.pl \\ ${ }^{3}$ Department of Marine Geology, Institute of Oceanography, University of Gdańsk, Al. Piłsudskiego 46, 81-378 \\ Gdynia, Poland; r.sokolowski@ug.gda.pl \\ ${ }^{*}$ corresponding author
}

\begin{abstract}
We present results of research into fluvial to aeolian successions at four sites in the foreland of the Last Glacial Maximum, i.e., the central part of the "European Sand Belt". These sites include dune fields on higher-lying river terraces and alluvial fans. Sediments were subjected to detailed lithofacies analyses and sampling for morphoscopic assessment of quartz grains. Based on these results, three units were identified in the sedimentary succession: fluvial, fluvio-aeolian and aeolian. Material with traces of aeolian origin predominate in these sediments and this enabled conclusions on the activity of aeolian processes during the Pleniglacial and Late Glacial, and the source of sediment supply to be drawn. Aeolian processes played a major role in the deposition of the lower portions of the fluvial and fluvio-aeolian units. Aeolian material in the fluvial unit stems from aeolian accumulation of fluvial sediments within the valley as well as particles transported by wind from beyond the valley. The fluvio-aeolian unit is composed mainly of fluvial sediments that were subject to multiple redeposition, and long-term, intensive processing in an aeolian environment. In spite of the asynchronous onset of deposition of the fluvio-aeolian unit, it is characterised by the greatest homogeneity of structural and textural characteristics. Although the aeolian unit was laid down simultaneously, it is typified by the widest range of variation in quartz morphoscopic traits. It reflects local factors, mainly the origin of the source material, rather than climate. The duration of dune-formation processes was too short to be reflected in the morphoscopy of quartz grains.
\end{abstract}

Keywords: fluvial to aeolian succession, aeolization of quartz sand grains, periglacial conditions, extraglacial zone

\section{Introduction}

The Late Pleniglacial and Late Glacial were periods of intensive climate changes generated by advances and retreats of the ice sheet, observed in all sedimentary environments. River valleys, particularly prone to such fluctuations, often bear a record of successive fluvial to aeolian settings (Kolstrup, 1980; Kasse, 1997; Van Huissteden et al., 2000;
Mol et al., 2000; Van Huissteden \& Kasse, 2001; Van Huissteden \& Pollard, 2003; Kasse et al., 2007; Zieliński et al., 2009, 2011, 2014a, b). Fluvio-aeolian sequences described from Pleistocene deposits are frequently accompanied by large-scale cryoturbations, abundant large ice-wedge casts (including syngenetic casts), frost cracks and aeolian deflation lags, found in the top or median parts of units (Vandenberghe, 1988; Kasse \& Vandenberghe, 1998; Mol 
et al., 2000; Van Huissteden et al., 2000; Zieliński et al., 2014a, b). Identification of such successions that yield only sparse botanical remains is based mainly on sediment texture and structure (Van Huissteden et al., 2000; Mol et al., 2000; Van Huissteden \& Kasse, 2001; Kasse, 2002), with grain size as a feature of particular interest. Other characteristics, e.g., mineral composition (including heavy minerals), as well as type of quartz grain surface in the sand fraction, are rarely considered, although such features have been examined by geomorphologists and geologists in stratigraphic, palaeogeographic and genetic studies (Goździk, 1980; Mycielska-Dowgiałło \& Woronko, 2004; Woronko, 2012; Woronko et al., 2013).

The objectives of the present paper are to analyse and discuss: (1) the type of quartz grain surfaces characteristic of fluvio-aeolian sedimentary successions, (2) the type of quartz grain surface as indicator of intensity of aeolian processes, (3) the importance of sandy material supplied from outside the accumulation area in relation to multiple sediment redeposition in situ, and (4) changes in climatic conditions and sedimentary settings in the extraglacial zone during the Last Glaciation.

\section{Study area}

The key sites are situated in the central part of the European Sand Belt (ESB; Koster, 1988) in Poland and western Ukraine, within an approximately 1,000 km long, E-W oriented area (Fig. 1A). Deposits from four sites, Postolin, Niwiska, Józefów and Berezno, were considered to be representative of the ESB and subjected to detailed textural analyses (Fig. 1B-E). The above-mentioned sites were selected on the basis of their location in the Last Glacial Maximum (LGM) foreland and on account of their varied geomorphological setting, including higher-lying river terraces and accumulated alluvial fans (Fig. 1). All sites are situated in the extraglacial zone outside the range of meltwater clastic material supply from the last continental ice sheet (Marks, 2002). Additionally, sediments at each site were assumed to provide a record of complete fluvial to aeolian succession.

The age of the sediments examined ranges from Middle Pleniweichselian to Early Holocene (Figs 2-5). Fluvial deposits generally accumulated during the Late Weichselian and their oldest portions at Józefów were dated as Middle Pleniweichselian. The transient fluvio-aeolian unit was deposited at the end of the Late Pleniweichselian and the beginning of the Late Weichselian. The age of aeolian sediments is Late Weichselian to Holocene (Zieliński et al., 2014b).

\subsection{Postolin}

This locality is in the eastern part of the Milicz Basin (part of the Głogów-Baruth ice-marginal valley, western Poland; Fig. 1B), within the northern dune, i.e. one of the two parallel, longitudinal, WNWESE oriented dunes. These dunes are c. $300 \mathrm{~m}$ apart and reach a maximum length of $2 \mathrm{~km}$ and a relative altitude of up to $7 \mathrm{~m}$, and are surrounded by aeolian sand cover with depressions and deflation remnants. In a northwesterly direction, they overlie a very gently inclined surface consisting of fluvial sands, while towards the east, the dune encroaches on glacial upland (Winnicka, 2007, 2008).

\subsection{Niwiska}

The site is situated on a high sandy terrace of the Wisłoka River valley (Sandomierz Basin, southern Poland; Fig. 1C; Mądry, 1994), within a crescent-shaped dune in a large dune complex adjacent to the eastern valley slope. This WNW-ESE oriented landform, with a c. $600 \mathrm{~m}$ long ridge and $10 \mathrm{~m}$ high front, includes a small blowout in its peripheral part (Fig. 1C).

\subsection{Józefów}

This locality is in the southeastern part of the Józefów Vale (Tomaszów Roztocze Region, southeast Poland; Fig. 1D), within a small parabolic dune $(3 \mathrm{~m}$ high at its front and $450 \mathrm{~m}$ long along the ridge).This dune is the outermost, southwesterly component of a WNW-ESE-oriented compound dune. The dune closes off the exit of a small, erosional valley entering the vale from the south (Fig. 1D; Kurkowski, 1997).

\subsection{Berezno}

This site is situated in the Słucz River valley, northeast of the town of Berezno (Volhynian Polesie Region, western Ukraine; Fig. 1E). This part of the valley includes an eroded fragment of a Weichselian terrace, located below the gentle slope of the Odranian (=Dnieper) valley outwash. The terrace is covered with various dunes. The wavy surface of the terrace has an altitude slightly exceeding $168 \mathrm{~m}$ 

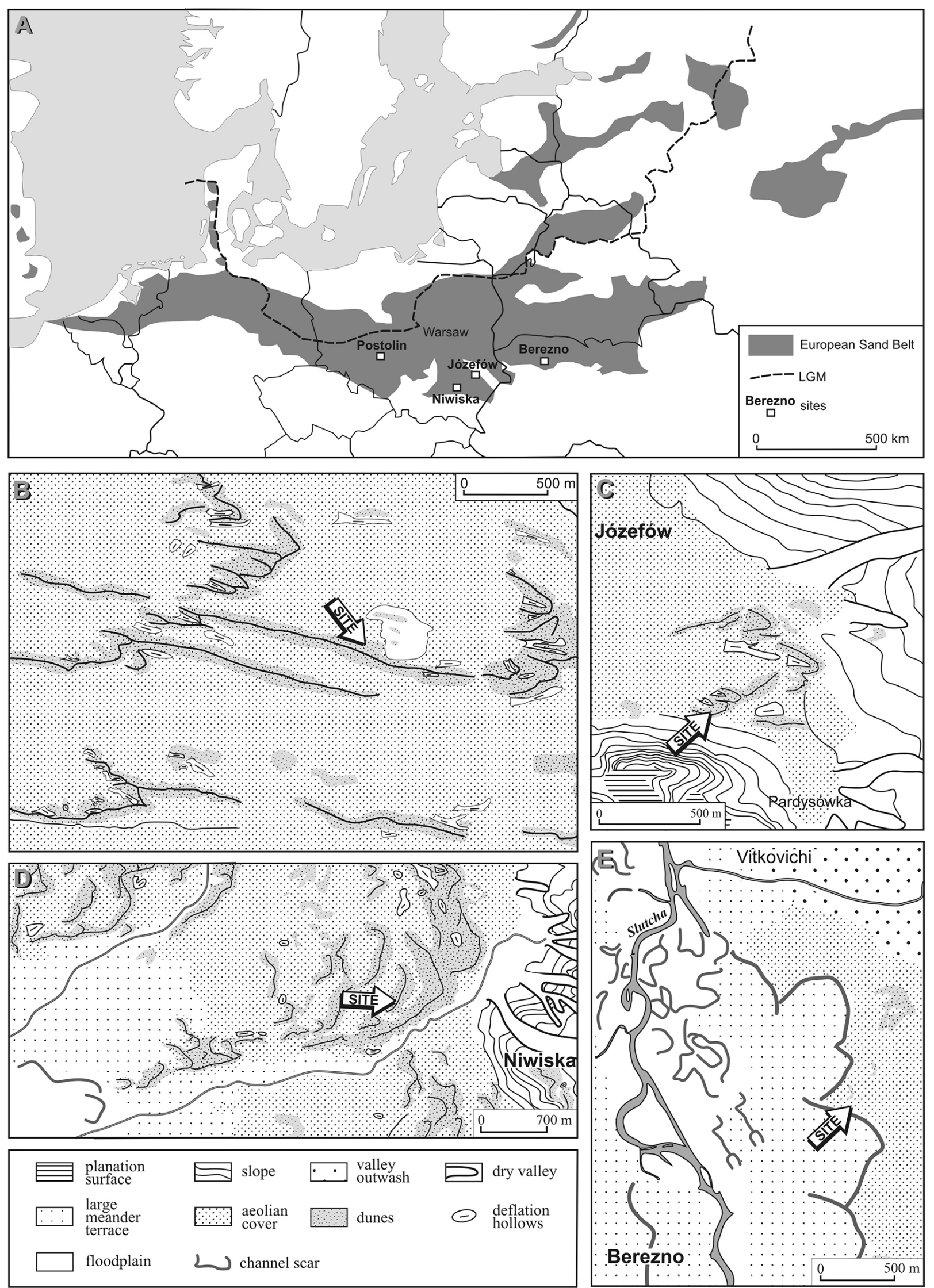

Fig. 1. A - Location of the sites studied in the European Sand Belt; B - Postolin; C - Niwiska; D - Józefów; E - Berezno. 
a.s.l. Easily recognised dune crests rise to a height of $176 \mathrm{~m}$ a.s.l.

\section{Methods}

Deposits from the localities studied were subjected to detailed lithofacies analysis with coding following Zieliński \& Pisarska-Jamroży (2012). Characteristics of periglacial structures and pedogenic levels were noted as well. Additionally, quartz grains of the sand fraction $(0.8-1.0 \mathrm{~mm})$ were examined in order to determine roundness according to the 9-degree classification by Krumbein (1941), and surface type, following the method of Cailleux (1942) as modified by Goździk (1980) and Mycielska-Dowgiałło \& Woronko (1998). In each sample, 100-150 grains from the $710-1000 \mathrm{~mm}$ size category were analysed and assigned to one of seven types (Table 1).

The TL age of the deposits analysed was determined at the University of Gdańsk (Fedorowicz, 2006) and the IR-OSL dating was done at the Research Laboratory for Quaternary Geochronology (RLQG) at the Tallinn University of Technology (Molodkov \& Bitinas, 2006).

\section{Results}

At each of the sites presented here, three facies types were distinguished: fluvial (lower unit), flu- vio-aeolian (middle unit) and aeolian (upper unit, developed as cover and/or dune sands) (Figs 2-5).

\subsection{Postolin}

\subsubsection{Fluvial unit}

The fluvial unit comprises a rhythmite of horizontally stratified sands (Sh) and horizontally laminated sandy silts (FSh) in the basal part (Fig. 2). Sands with trough cross-stratification (St), grading into sands with ripple cross-lamination (Sr) and silty sands of deformed structure (Sd) in the top part. The unit is marked by two generations of synsedimentary pseudomorphs, developed after ice-wedge casts, and small-scale, finger-shaped load-cast structures. The lower and upper layers of wedges correspond to the top of the sandy-silty rhythmite and the top of the unit, respectively. The lower and middle units are separated by an aeolian pavement which represents a record of long-term deflation preceding the deposition of the fluvio-aeolian unit (Fig. 6A).

The unit shows a strong predominance of moderately rounded grains, frosted only in their most convex parts (EM/RM; 72-81\%). The frequency of RM grains generally does not exceed $10 \%$, but gradually decreases upwards (Fig. 2). The content of moderately rounded and shiny grains (EM/EL) amounts to c. $10 \%$ in the entire unit, and the content of grains classified as 'other' ranges between 2.3 and $6.7 \%$ (Fig. 2).

Table 1. Type of roundness and frosting of quartz sand grains according to Cailleux (1942) as modified by Goździk (1980) and Mycielska-Dowgiało \& Woronko (1998).

\begin{tabular}{|c|c|c|c|}
\hline $\begin{array}{l}\text { Type of } \\
\text { grain }\end{array}$ & $\begin{array}{l}\text { Roundness of } \\
\text { grain (Krum- } \\
\text { bein, 1941) }\end{array}$ & Description & Processes responsible for grain formation \\
\hline RM & $0.7-0.9$ & $\begin{array}{l}\text { Very well-rounded with complete- } \\
\text { ly mat surface }\end{array}$ & $\begin{array}{l}\text { Very long duration of abrasion in aeolian environ- } \\
\text { ment }\end{array}$ \\
\hline $\mathrm{EM} / \mathrm{RM}$ & $0.3-0.9$ & $\begin{array}{l}\text { Moderately rounded, mat surface } \\
\text { only on convex parts of grains }\end{array}$ & $\begin{array}{l}\text { Short-time abrasion in aeolian environment marked } \\
\text { only on convex parts of grains }\end{array}$ \\
\hline EL & $0.7-0.9$ & $\begin{array}{l}\text { Very well-rounded, entire surface } \\
\text { smooth and shiny }\end{array}$ & $\begin{array}{l}\text { Combination of abrasion and solution in fluvial or } \\
\text { beach environment. Long duration of processes }\end{array}$ \\
\hline EM/EL & $0.3-0.6$ & $\begin{array}{l}\text { Moderately rounded, smooth and } \\
\text { shiny surface }\end{array}$ & $\begin{array}{l}\text { Combination of abrasion and solution in fluvial or } \\
\text { beach environment }\end{array}$ \\
\hline $\mathrm{C}$ & - & $\begin{array}{l}\text { Crushed/broken. Only crushed } \\
\text { surface fresh, remaining parts } \\
\text { with microstructures typical of } \\
\text { transport or weathering }\end{array}$ & $\begin{array}{l}\text { Crushing in all types of environments but with high- } \\
\text { est intensity in subglacial environment or aseffect of } \\
\text { frost weathering }\end{array}$ \\
\hline NU & $0.1-0.2$ & $\begin{array}{l}\text { All surfaces fresh: corners sharp } \\
\text { and angular }\end{array}$ & $\begin{array}{l}\text { Crushing and abrasion in glacial environment; me- } \\
\text { chanical weathering in situ, e.g., frost weathering }\end{array}$ \\
\hline O (other) & $0.1-0.9$ & $\begin{array}{l}\text { Very intensively weathered } \\
\text { surface by silica precipitation or } \\
\text { solution in situ; traces of transport } \\
\text { invisible }\end{array}$ & $\begin{array}{l}\text { Solution or precipitation in soil profile, hot desert or } \\
\text { periglacial environment }\end{array}$ \\
\hline
\end{tabular}




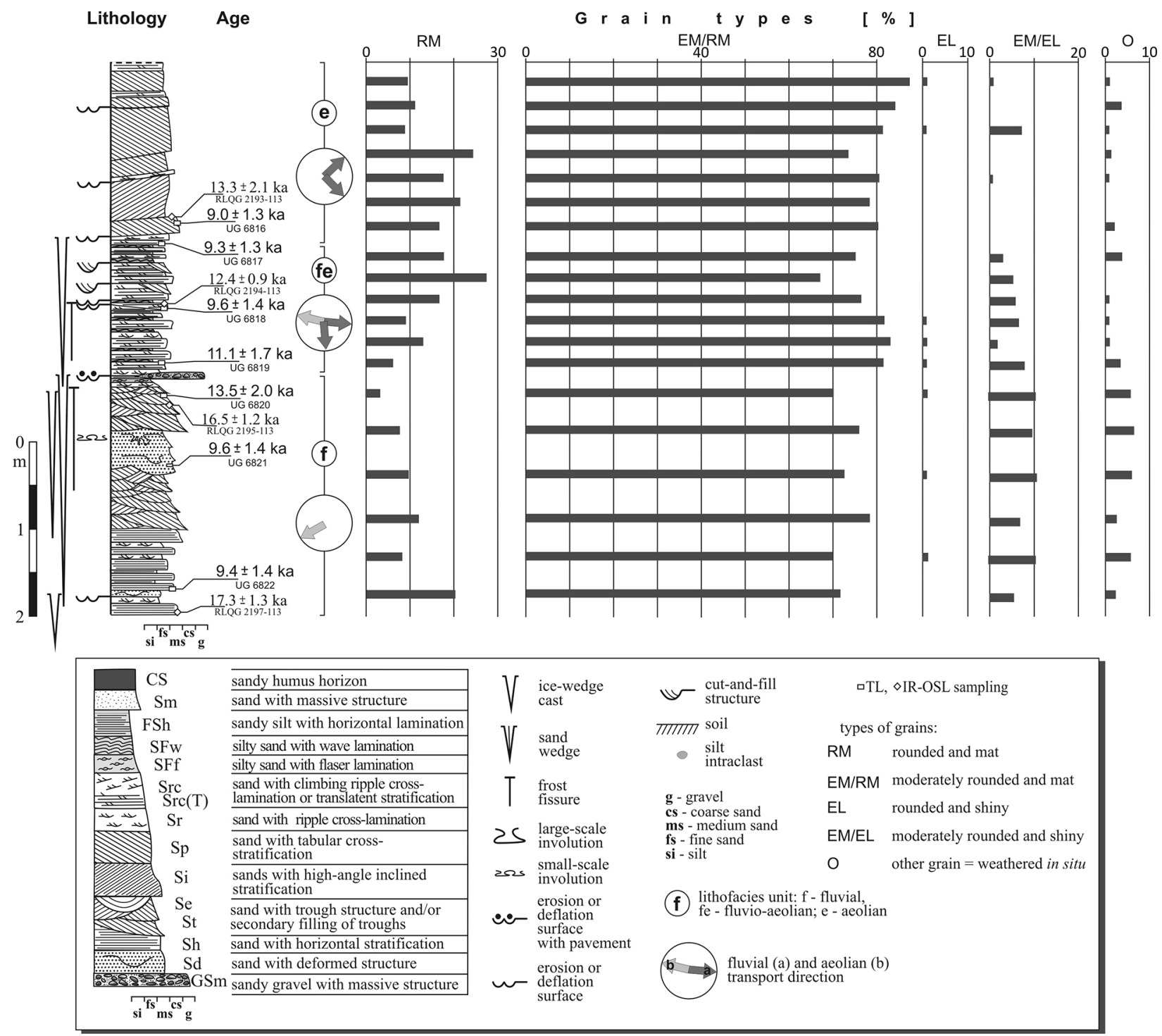

Fig. 2. Postolin: rounding and frosting of quartz grains.

$\mathrm{NU}=$ fresh, angular; $\mathrm{RM}$ = rounded and mat; $\mathrm{EL}=$ rounded and shiny; $\mathrm{EM} / \mathrm{RM}=$ moderately rounded and mat; $\mathrm{EM} / \mathrm{EL}=$ moderately rounded and shiny; $\mathrm{C}=$ broken; $\mathrm{O}=$ other, coated by silica or partly dissolved.

Fluvial deposits accumulated in channels functioning on an alluvial fan with continuous permafrost (Fig. 2). Roundness and frosting analyses of quartz grain surfaces demonstrate their low diversity within the section.

\subsubsection{Fluvio-aeolian unit}

This consists of sands showing a translatent stratification $(\operatorname{Src}(\mathrm{T}))$, interbedded with sands of ripple cross-lamination (Sr) or silty sands of wavy lamination $(\mathrm{SFw})$. The unit includes occasional cutand-fill structures and numerous synsedimentary pseudomorphs, developed after ice-wedge casts (Fig. 6A).

The deposits still include mainly EM/RM grains, but are accompanied by a higher propor- tion of well-rounded and mat (RM) grains, in comparison to the fluvial unit. RM values increase upwards reaching a maximum value of $27.4 \%$ at the top of this unit. The frequency of moderately rounded and shiny grains (EM/EL) reaches values below $10 \%$ and decreases to zero at the top of the series (Fig. 2).

These deposits formed in an aeolian environment and were redeposited in periods of intensive nival melt.

\subsubsection{Aeolian unit}

This unit comprises sands with large-, mediumand small-scale planar cross-stratification (Sp) and occasional translatent stratification (Fig. 6B). These deposits provide a record of the functioning of 
a longitudinal (seif) dune (Tsoar, 1982; Pye \& Tsoar, 1990; Figs. 2, 6B).

The unit shows a distinct change in quartz grain morphoscopy (Fig. 2). Nearly the entire base of the unit is formed of mat and mostly moderately rounded grains (EM/RM; up to $88 \%$ ), accompanied by well-rounded grains (RM; up to $>20 \%$ ). In the top part, the content of RM grains drops below $10 \%$, while amounts of shiny (EM/EL) and 'other' grains increase (Fig. 2).

\subsection{Niwiska}

\subsubsection{Fluvial unit}

The fluvial unit includes sands with large- (base) and medium-scale (top) trough cross-stratification $(\mathrm{St})$, turning laterally into sands with horizontal stratification (Sh) and ripple cross-lamination (Sr; Fig. 6C).

The results of our analysis of quartz grain morphoscopy show that the lower part of the deposit contains mainly mat grains, both moderately and very well rounded (Fig. 3). The frequency of RM grains gradually increases towards the top, with large-scale trough cross-stratification (St), and finally reaches a constant level of c. 10\%. RM and $\mathrm{EM} / \mathrm{RM}$ grains, increasing in number, replace the disappearing EL and EM/EL grains, the content of which decreases from c. 15\% at the base to zero EL grains at the top of the series. The frequency of EM/ EL grains increases again at the top of the unit, in sediments with medium-scale trough cross-stratification (St) (Fig. 3).

The sediments illustrate the functioning of a braided river, marked by intensive aggradation. The river existed under periglacial conditions, as evidenced by syngenetic ice-wedge casts, found in the uppermost and middle parts of the unit, mainly in abandoned valley segments.

\subsubsection{Fluvio-aeolian unit}

Deposits of this unit are approximately $2 \mathrm{~m}$ thick and are dominated by the Src(T) lithofacies and cutand-fill structures (Fig. 6D). Similar to the fluvial unit, EM/RM and RM grains predominate. However, the proportion of RM grains gradually increases upwards and reaches the maximum value at the top of the section (Fig. 3). The sediment properties indicate a record of aeolian accumulation and redeposition resulting from concentrated subcritical ephemeral flow.

\subsubsection{Aeolian unit}

This upper unit comprises mainly sands with translatent stratification $(\operatorname{Src}(\mathrm{T}))$, laterally accompanied by sands with inclined stratification (Si). Sediments formed within a stationary crescent-shaped dune (Zieliński et al., 2014a). Compared to the fluvio-aeolian unit, the aeolian unit shows a noticeable

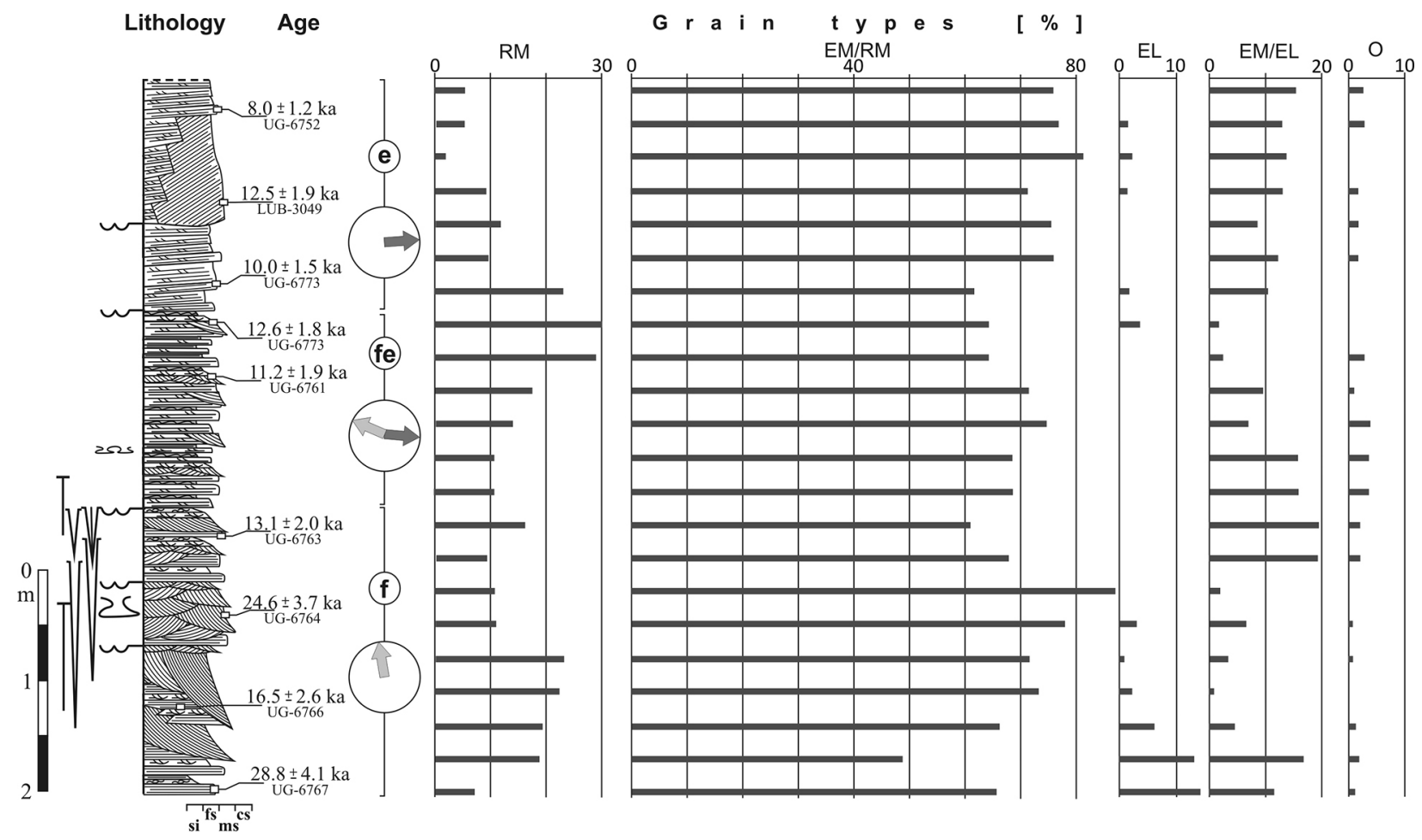

Fig. 3. Niwiska: rounding and frosting of quartz grains (see Fig. 2). 
decrease in the content of RM grains, replaced by $\mathrm{EM} / \mathrm{RM}$ and moderately rounded and shiny EM/ EL grains (Fig. 3).

\subsection{Józefów}

\subsubsection{Fluvial unit}

The fluvial unit, identified at the base of the deposits, includes two sedimentary cycles: sands with trough cross-stratification (St) and with a scale decreasing up the cycle, and horizontally stratified sands (Sh) marked by erosion and deformation at the contact zone (Fig. 6E).

Mat grains of the EM/RM and RM types predominate in these deposits. In the lower part of the unit, the proportion of very well-rounded RM grains is high (max. $40 \%$ ) but varies, while in the horizontally stratified sands (Sh), it shows a decrease to a constant level of c. 10\%, accompanied by a slight increase in EM/RM grains and large numbers of EM/EL, EL and 'other' types of grains (Fig. 4).

These sediments, comprising syngenetic icewedge casts as well as frequent fine cracks and load casts, provide evidence of the presence of a shallow braided river under periglacial conditions (Figs. 4, 6E).

\subsubsection{Fluvio-aeolian unit}

This unit comprises a rhythmite of fine- and medium-grained horizontally stratified sands (Sh), silty sands with wavy lamination (SFw) and sands with climbing ripple cross-lamination $(\operatorname{Src}(\mathrm{T}))$. They include sands with trough cross-stratification (St) or cut-and-fill structures (Figs. 4, 6E, F). Three generations of small-scale involutions were also recorded in this set.

In the fluvio-aeolian unit, EM/RM and RM grains have a total frequency varying between 70 and $90 \%$. The RM content slowly, but constantly, increases upwards and reaches maximum values at the top. At the same time, grains of all other types disappear (Fig. 4). These sediments illustrate aeolian deposition on humid (SFw) or dry $(\operatorname{Src}(\mathrm{T}))$ surfaces, and subsequent redeposition in incidental supercritical (Sh) or subcritical (St) flows (Figs. 4, 6F).

\subsubsection{Aeolian unit}

The upper unit, comprising mainly mixedgrained sands of inclined stratification (Si) with reactivation surfaces, provides a record of deflation and subsequent accumulation at the lee side of a migrating dune (Figs. 4,6F). Similar to the underlying deposits, the unit is composed mainly of EM/ RM and RM grains, reaching values as high as $90 \%$. However, it should be noted that EM/RM grains clearly predominate, while the RM content does not exceed $12 \%$ and varies strongly (Fig. 4).

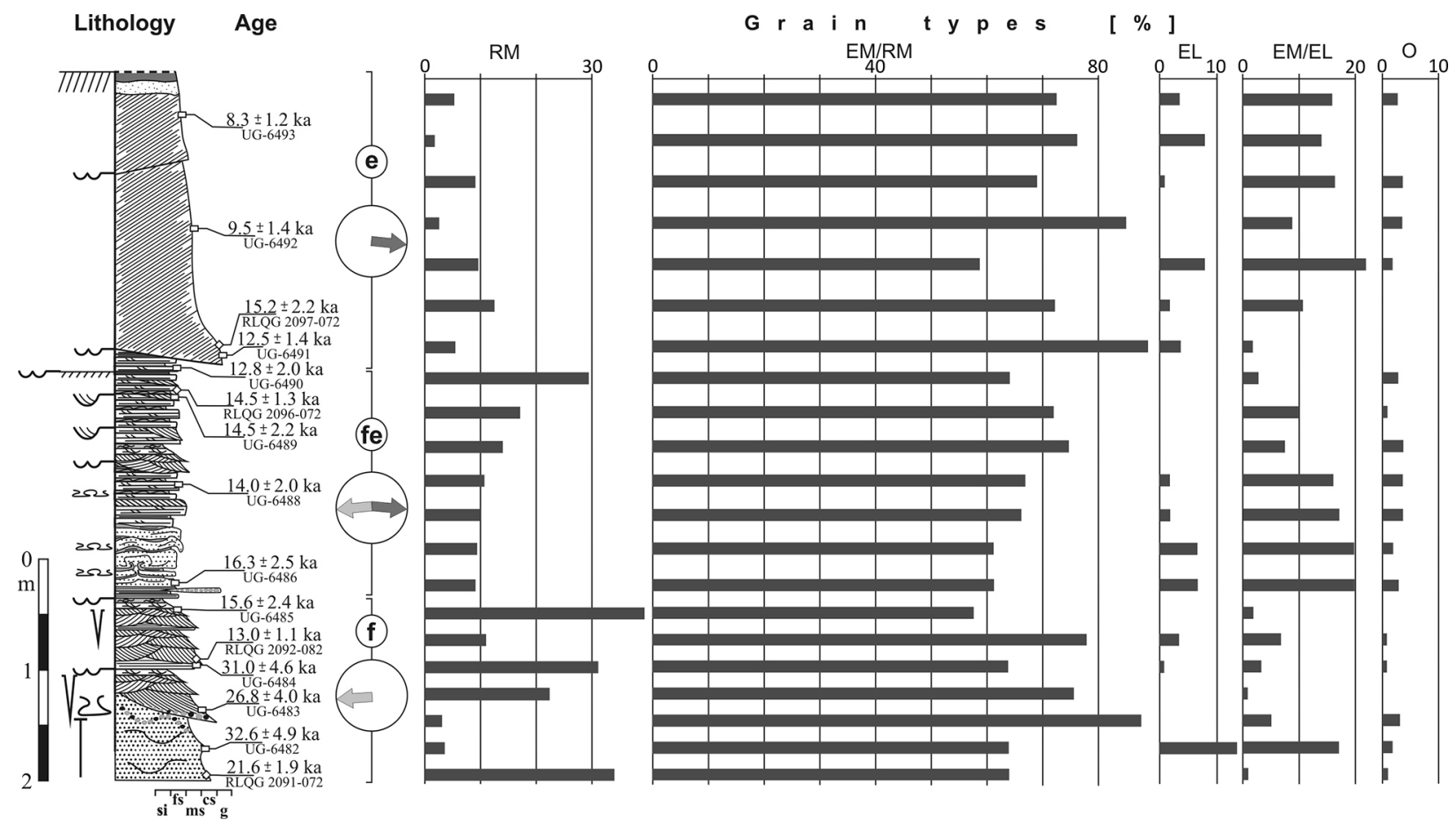

Fig. 4. Józefów: rounding and frosting of quartz grains (see Fig. 2). 


\subsection{Berezno}

\subsubsection{Fluvial unit}

The fluvial unit documents sedimentary successions with alternating sand and silt layers (Fig. 5, 6G). The sandy interval consists mainly of sands with trough cross-stratification (St) and planar cross-stratification (Sp), while the silt-sand interval includes lithofacies with ripple cross-lamination and flaser lamination (SFr, Ff). This unit contains also pseudomorphs of ice wedges overlain by sandy wedges, as well as large-scale involutions at the top (Fig. 6G). Periglacial structures indicate deposition by a braided and anastomosing river system, under harsh climatic conditions with continuous permafrost (Zieliński et al., 2009, 2014a) (Fig. 5).

\subsubsection{Fluvio-aeolian unit}

The middle unit is represented by a rhythmite of horizontally stratified sands (Sh) and sandy silts with wavy lamination (FSv). The basal part includes an erosional cut filled with sands of trough cross-stratification (St; Figs. 5, 6H).

\subsubsection{Aeolian unit}

The upper unit comprises a rhythmite of sands with translatent stratification $(\operatorname{Src}(\mathrm{T}))$ or planar cross-stratification (Sp) and sandy silts with horizontal lamination (FSh) or massive structure (FSm; Fig. 5).

All three units are dominated by mat grains (EM/RM and RM). However, the amounts of specific grain types do not display clear increasing or decreasing trends, as observed in the three other
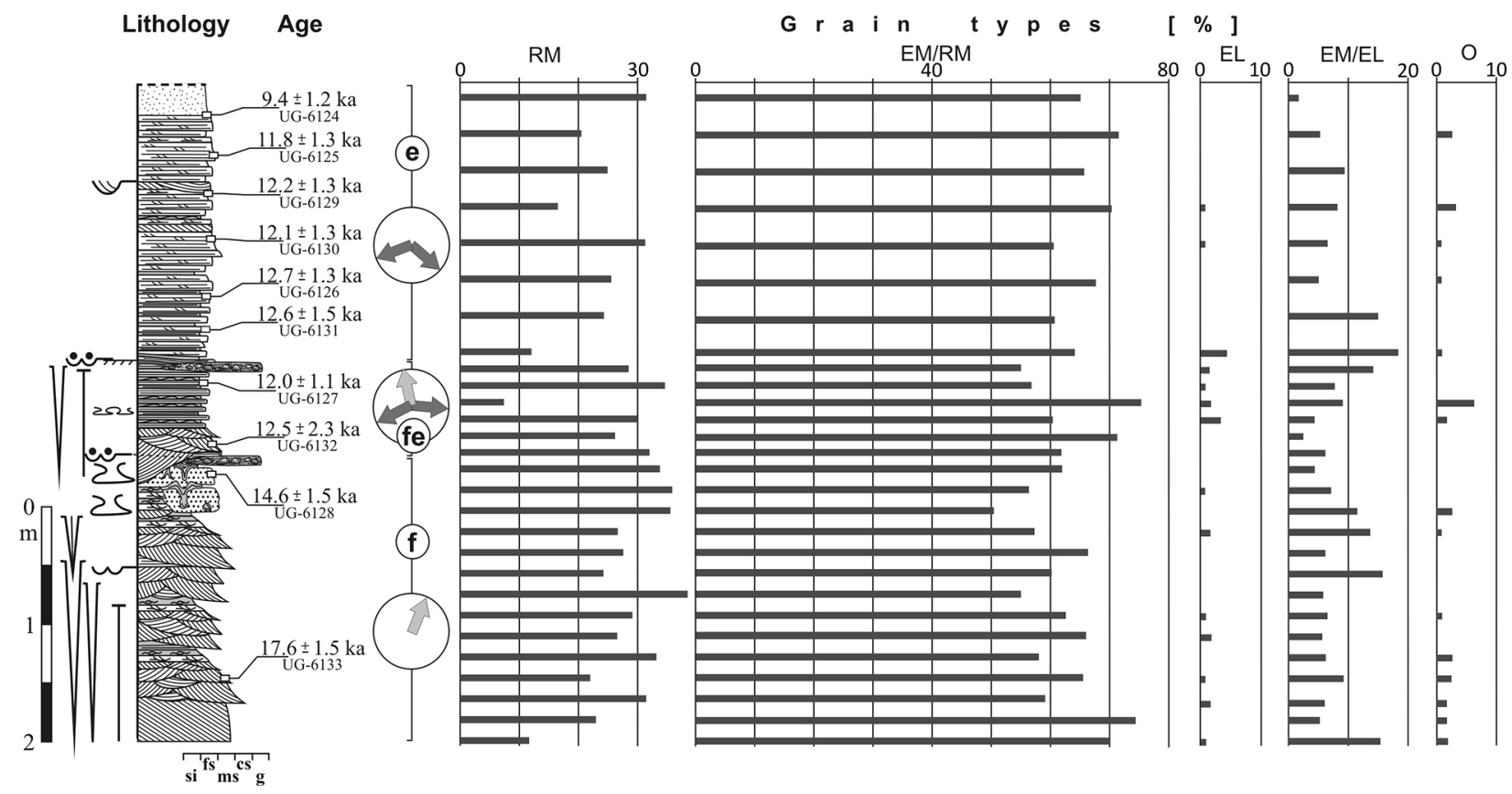

Fig. 5. Berezno: rounding and frosting of quartz grains (see Fig. 2).

Fig. 6. Examples of depositional and cryogenic structures documented.

Postolin: A - contact zone of fluvial (f) and fluvio-aeolian (fe) units, marked by deflation (aeolian) pavement (black arrow), pseudomorphs after ice wedges present in both units (white arrow); B - aeolian unit, many deflation surfaces (black arrow).

Niwiska: C - fluvial unit with pseudomorph after ice wedge (white arrow) and cryoturbations (red arrow); D - uppermost part of fluvial unit (f) with pseudomorph after ice wedge (white arrow), corresponding to top of unit and floor of fluvio-aeolian unit (fe) with cut-and-fill structure (grey arrow).

Józefów: E - fluvio-aeolian unit with small-scale involutions (red arrow) and cut-and-fill structure (grey arrow); F complete fluvial-aeolian sedimentary succession; fluvial unit (f), fluvio-aeolian unit (fe) and aeolian unit developed in the form of aeolian sediments (e1) and dune sediments (e2) separated by deflation surface (black arrow).

Berezno: G - fluvial unit with two generations of large-scale involutions (red arrow) in top and unit wedges (white arrow); H - sedimentary succession at site, top of fluvial unit (f) deformed by large-scale involutions (red arrow), aeolian unit (e) separated from fluvio-aeolian unit (fe) by deflation surface with pavement (black arrow); pseudomorph after ice wedge (white arrow) corresponding to deflation surface. Other explanations in Figure 2. 


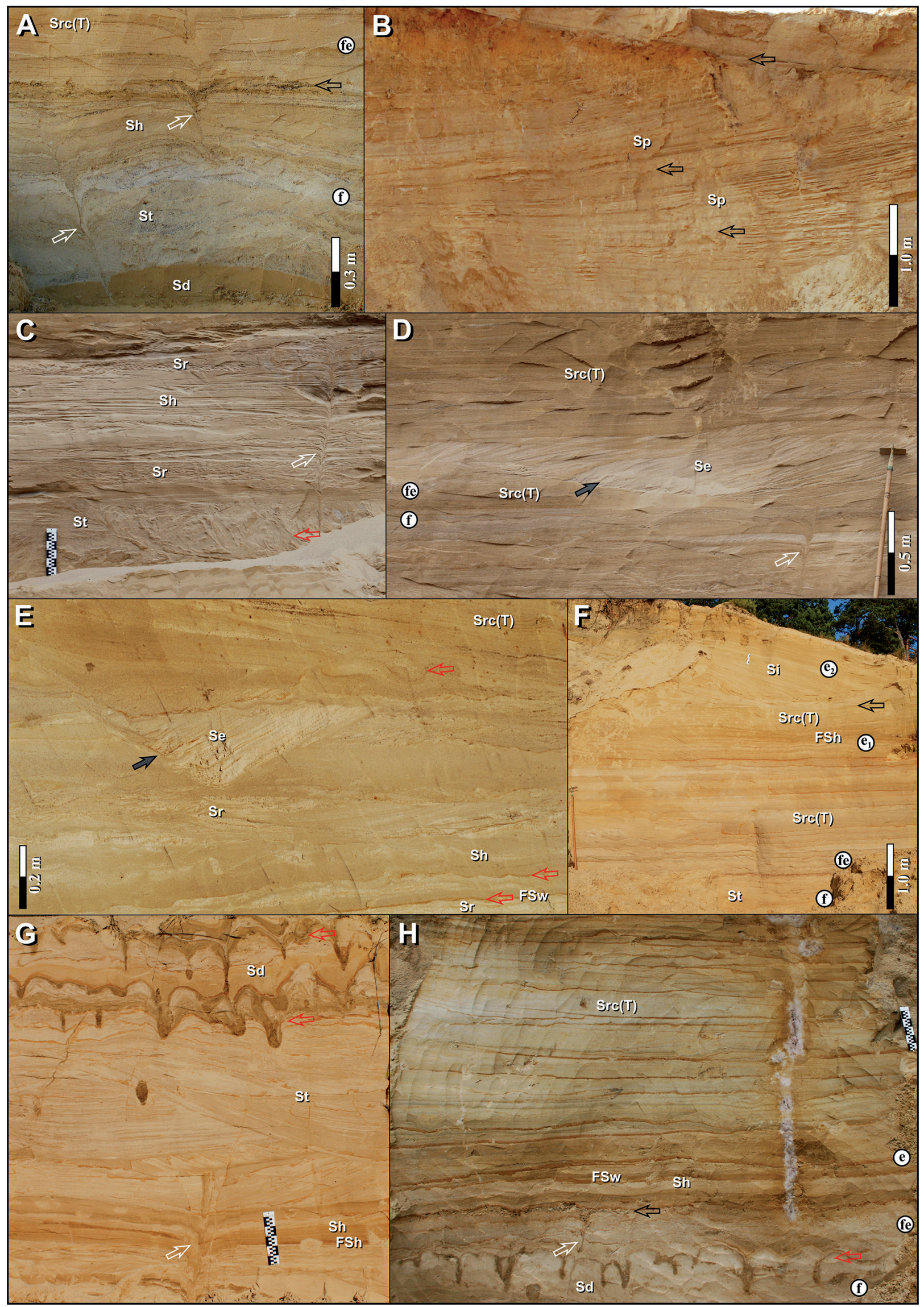


sections, particularly where RM grains are concerned. Moderately rounded and shiny EM/EL grains were recorded at levels of c.10-15\% throughout the section (Fig. 5).

\section{Palaeoclimatic and palaeoenvironmental interpretation}

All sites discussed in the present study were formerly situated in the LGM (Last Glacial Maximum) foreland (Fig. 1), which explains why they could be expected to provide evidence of changes in climate, sedimentary settings and source of deposits during the entire MIS 2 and older periods. The Late Pleniglacial (MIS 2) generally is divided into two stages. The older stage was the phase of maximum cold, resulting from the formation and maximum extent of the ice sheet (28-18 ka), which supported the development of various periglacial phenomena and continuous permafrost. The younger period (18-13 ka) was marked by a temperature rise and progressive disappearance of permafrost conditions (Huijzer \& Vandenberghe, 1998; Mol et al., 2000).

\subsection{Sources of deposits}

Sources of deposits, particularly of those of the fluvial units, remain an open issue. In the LGM foreland, aeolian processes were already under way at the end of the Saalian glaciation (Goździk, 2007), while south of the Saalian maximum, they were active also during older periods (Schokker et al., 2005; Woronko, 2012). However, they were also recorded from older phases of the Weichselian. A very high content of aeolian grains, including $\mathrm{RM}$, was reported for deposits dated as the younger part of stage 3 (younger than $\sim 45 \mathrm{ka}$ ) and as 60 ka (Van Huissteden \& Pollard, 2003; Dzierżek \& Stańczuk, 2006; Kalińska, 2010; Marks et al., 2014). Already Dylik (1969) suggested that the origin of 25.2 kyr old sediments from Bełchatów might have resulted from aeolian processing occurring not only during the Late Pleniglacial, but also shortly after the Brørup. On the other hand, Goździk (1980) assumed that the intensive aeolian processes during the Weichselian begun much later than the Brørup. The potential source of sandy material, which could be incorporated into aeolian transport, has a different genesis at each site, as a result of differences in local geological structure. In the case of the Postolin site, the material was of glacigenic/fluvioglacial origin, derived mainly from erosion of end moraines of the Saalian glaciation (Winnicka, 2007). At Berezno and Niwiska, material of the fluvial unit was of allochthonous origin. It came mostly from long-term transportation from recharge areas situated to the south of the above-mentioned sites. The Carpathians were a source of sediments at Niwiska, and the Volhynian (Ukrainian) shield at Berezno (Mądry, 1994). In the case of Józefów, these were primarily Miocene sands, glacial till and deluvial deposits from the direct vicinity (Kurkowski, 1997).

The material forming the dunes and cover sands came from other sources, including former aeolian series and fluvioglacial sediments. A large diversification of the degree and nature of quartz grains processing at the individual sites (key sites) reflect changes in seasonal and long-term directions of transportation, which is best seen at Postolin (Fig. 2) and a gradual increase in the range of the deflation process, which reaches sediments at increasingly greater depths. Contrary to the dune fields in large river valleys, there was no material available from river terraces with similar textural characteristics at the sites studied (Ruegg, 1983; Klatkowa, 1996).

\subsection{Fluvial unit}

The age of the fluvial unit examined in the area of the European Sand Belt has been dated as Middle

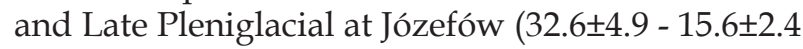
ka; Fig. 4) and as Late Pleniglacial and Oldest Dryas at Postolin, Niwiska and Berezno (28.8 $\pm 4.1-13.1 \pm 2.0$ ka; Figs 3, 5) (Zieliński et al., 2014b). The sand fraction of the alluvial deposits was obviously dominated by mat, well- and very well-rounded RM and EM/RM grains (Figs 2-5). However, such a surface type resulted from abrasion occurring in the previous aeolian environment (Mycielska-Dowgiałło \& Woronko, 1998; Woronko, 2001). The frequency of these grains did not noticeably change in a west-east gradient, except for the easternmost site (Berezno) with a slightly higher and more stable content of completely mat and very well rounded RM grains in the vertical section. Grains representing different, e.g. aquatic (EL and EM/EL grains) or weathering ('other' grains) sedimentary environments were recorded only in small amounts. The sediment characteristics described clearly show that fluvial alluvia were supplied mainly by wind-transported grains. Uplands surrounding the valleys were subjected to intensive deflation and all dry, exposed and unconsolidated sandy deposits may have been included in aeolian transport (Fig. 7). These sediments accumulated on the floodplain and aeolian 


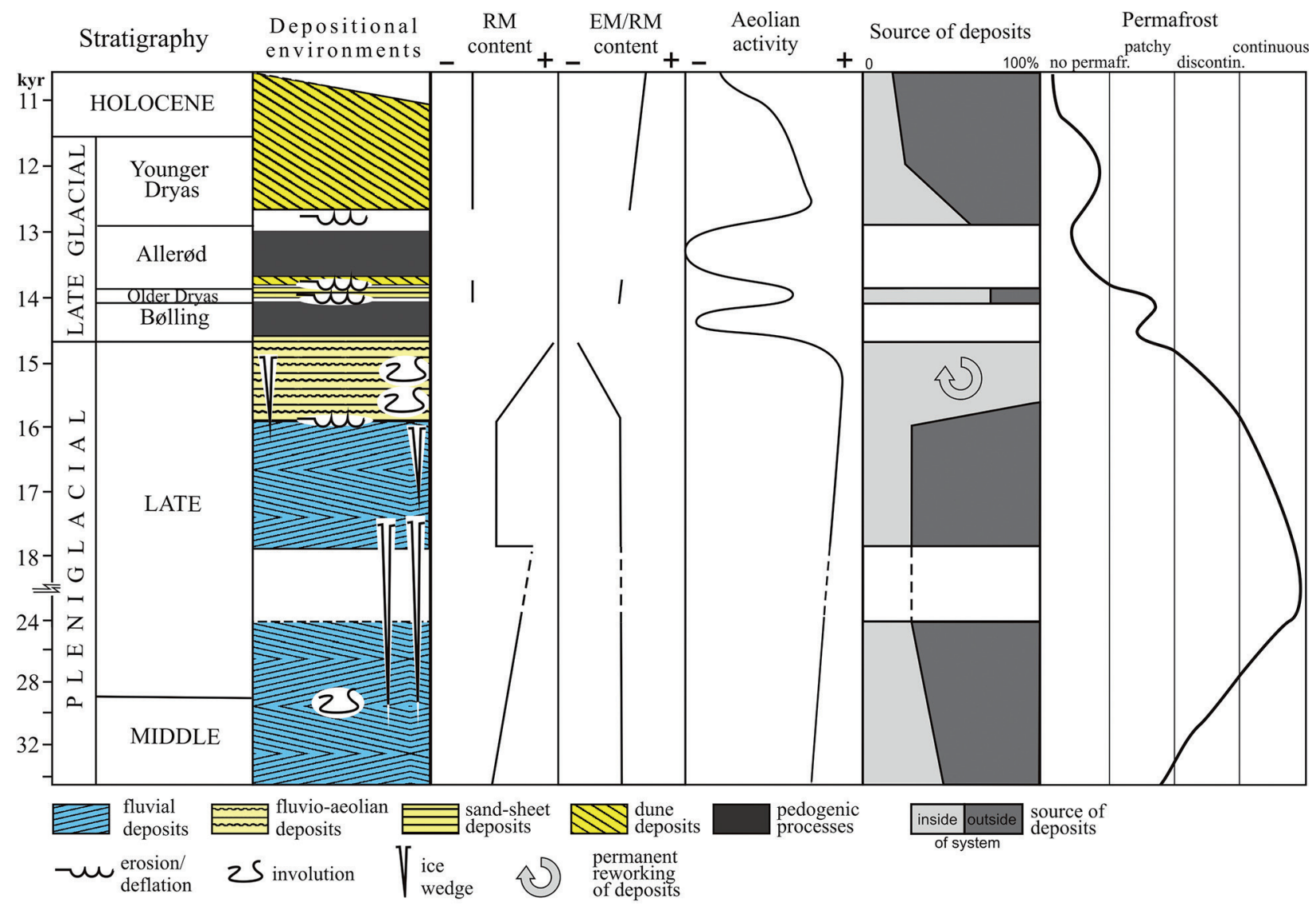

Fig. 7. The model of fluvio-aeolian deposition: morphology of sand grains and interpretation of palaeoenvironmental conditions.

materials eroded from valley slopes (Kasse, 2002) were also redeposited. The large supply of aeolian material into the valley accounted for a high aggradation ratio (Zieliński, 2007). Similar depositional environments have been recorded from numerous river valleys in the Netherlands, Germany and Poland (Koster, 1988, 2009; Turkowska, 1994; Mol et al., 2000; Van Huissteden et al., 2000; Kasse et al., 2003; Mycielska-Dowgiałło \& Woronko, 2004; Goździk, 2007; Zieliński, 2007; Woronko, 2012). The predominance of aeolian grains in the alluvia could indicate cold climatic conditions in the valleys and immediate surroundings, as well as active aeolian processes, while the occurrence of syngenetic icewedge casts in the sediments provides evidence of permafrost conditions (Kasse et al., 2007; Fig. 7).

The lower part of the fluvial unit documents the role of aeolian processes, intensified in the area as the climate became colder and drier. The processes were activated most likely during winter (Koster, 1995). Sand was released from the frozen soil by sublimation (McKenna Neuman, 1990, 1993, 2004; Kasse et al., 2007), and repeatedly redeposited before final supply to the alluvia. The analysis of quartz grain morphoscopy indicated that aeolian processes were strong and synchronous with accumulation in fluvial environments, but the preservation of aeolian sediments was low (Kasse, 1997; Sidorchuk et al., 2001).

The upper part of the fluvial unit, in which the disappearing RM grains are accompanied by still very frequent EM/RM grains, provides evidence of the continuation of very active aeolian processes (Fig. 7). The material could have become more easily accessible for aeolian transport than during accumulation of the lower part of the unit. Consequently, the deposition was extensive and burial rapid, which prevented repeated redeposition and led to a higher degree of rounding and frosting of grains. This observation may be supported by the fact that in the Niwiska and Berezno sections, the top parts of the fluvial unit are marked by large-scale involutions (Figs. 3, 5). Their record, combined with the presence of ice-wedge casts, indicates degradation of the ice-rich permafrost as a result of climate ameliorations (Kolstrup, 1980; Vandenberghe, 1988; Van Huissteden et al., 2000; Kasse et al., 2007). Lowering of the permafrost top and drying of the surface sediment layer led to more material being accessible for aeolian transport (Kasse, 1997). 
In the Postolin section, the fluvial unit, which includes limited, upward-decreasing amounts of RM grains (Fig. 2), may be represented only by its upper part. An upward decrease in RM grains was not recorded at Berezno, presumably due to: (1) much longer persistence of conditions favourable to aeolian processes accompanying deposit accumulation, or (2) erosion of the uppermost sediments of the fluvial unit.

Accumulation of the fluvial unit was accompanied by intensive aeolian processes (Fig. 7). Results obtained indicate the increasing importance of such processes in the supply of sand material to the regions of deposition. Their maxima presumably occurred in the 24-18 ka interval. However, there are no sediments from this period to substantiate this.

\subsection{Fluvio-aeolian unit}

Similar to the fluvial unit, deposits of the fluvio-aeolian series, dated as $16.3 \pm 2.5-12.0 \pm 1.1 \mathrm{ka}$ (Zieliński et al. 2014b), were clearly dominated by $\mathrm{EM} / \mathrm{RM}$ and RM grains representing the aeolian environment at each examined site (Figs 2, 4 and 6). At all localities, except for Berezno (Fig. 5), the content of RM grains gradually increased upsection. Such features show that the deposits were simultaneously affected by aeolian processing and fluvial accumulation, and afterwards repeatedly redeposited in an aeolian environment (Good \& Bryant, 1985; Goździk, 1995; Woronko, 2012; see Fig. 6). The relatively limited thickness of fluvio-aeolian sediments (i.e. from several tens of centimetres to $2.5 \mathrm{~m}$ ), compared to similar series from the Netherlands (Ruegg, 1983; Kasse, 2002) and Germany (Mol et al., 2000), indicates a small supply of material from elsewhere. This may result from low availability of sand material around the locations analysed. The processes were accompanied by progressive degradation of permafrost, as concluded from the absence or infrequent presence (exclusively at the base of the unit) of loading structures. However, the occurrence of small-scale involutions and lack of ice wedges in this unit indicate cool climatic conditions and deep seasonal frost with Mean Annual Air Temperature (MAAT) $<-1^{\circ} \mathrm{C}$ (Kasse et al., 2003). Such conditions intensified infiltration and drying of the surface sediment layer, making it prone to incorporation into aeolian transport and intensive deflation, producing pavement gravels (Figs. 2-5; Van Huissteden et al., 2000). Results obtained indicate that aeolian processes during the Late Pleniglacial were most intensive and efficient during accumulation of the fluvio-aeolian unit. This finding was confirmed by studies carried out in other parts of Europe where the maximum aridity was dated as between 18.6 and $16.9 \mathrm{ka}$ and the most intensive activity of aeolian processes as Late Pleniglacial (Ruegg, 1983; Van Huissteden \& Kasse, 2001; Kasse et al., 2007).

\subsection{Aeolian unit}

The luminescence age of this unit (15.2-8 ka) indicates accumulation during cold weather conditions of the Late Glacial and Early Holocene (Zieliński et al. 2014b; see Fig. 7). This is consistent with generally accepted (in the literature) aeolian accumulation/dune-formation phases (compare Kozarski \& Nowaczyk, 1991; Kasse, 2002; Goździk, 2007; Kasse et al., 2007; Zieliński et al., 2014b). Nevertheless, most of the material was deposited during short spells in the Older and Younger Dryas. This fact is clearly reflected in the morphoscopic characteristics of quartz grains from the aeolian unit, because the period was too short for aeolian transport to result in increased roundness of quartz grains (Mycielska-Dowgiałło, 1993, 2001; Goździk, 2007). In the sections examined, the aeolian transport is reflected in the predominance of EM/RM grains, with a relatively minor increase in their content throughout the section at the expense of EM/EL grains (Postolin and Berezno; Figs. 2, 5). At other sites, such a trend is indiscernible and the content of EM/EL grains increases. This fact, as well as much smaller content of RM grains in relation to the underlying units, indicate that sediments of units 1 and 2 were not the sole source of these deposits. This means that dune material was supplied mostly from outside the systems studied (Zeeberg, 1998). Postolin seems to be an exception - initially the content of $\mathrm{RM}$ is similar to that in unit 2, but it drops rapidly in the uppermost part and becomes similar to that in unit 1 . This can be explained by extraction of the local material for the construction of a dune. Initially, erosion affected the fluvio-aeolian sediments; however, supply from the underlying fluvial sediments proceeded with increasing depth of a wind-blown hollow. The groundwater level, which at that time was significantly lowered, was the sole determining factor (Kasse, 1997).

A clear decrease in the RM content may also be explained by a change in the recharge area where morphoscopic characteristics of sediments differed significantly. This option may be corroborated by two different directions of dune-forming wind reflected in characteristics of lithofacies units (Fig. 2) and a similar distribution of these properties at 
Niwiska (Fig. 3), and, to a lesser extent, at Józefów (Fig. 4). The content of RM grains at these localities drops below the level observed in the underlying units, which clearly implies a different source of the material; likely, this was due to the reconstruction of the general atmospheric circulation during the Late Glacial period (Isarin et al., 1997; Zeeberg, 1998).

\section{Conclusions}

Analysis of quartz grain morphoscopy showed that surface type and rounding degree are good tools for the reconstruction of the intensity and duration of aeolian processes in fluvial to aeolian depositional successions.

- The fluvial unit at sites in eastern Poland and western Ukraine is characterised by dichotomy. The borderline between both subunits is emphasised by a stratigraphic gap comprising the climatic pessimum (22-18 ka) and a clear erosional boundary. In the lower part, an increase in the content of quartz grains with signs of aeolian transport is observed. This indicates deteriorating climatic conditions during the Last Glacial Maximum (MIS 2). Furthermore, aeolian transport was increasingly important in the supply of sandy material to river valleys. The smaller content of grains with aeolian origin and numerous traces of permafrost degradation in the upper part of the fluvial unit indicates milder climatic conditions during the Late Pleniglacial.

- The increasing number of very well-rounded aeolian (RM) and moderately rounded aeolian $(\mathrm{EM} / \mathrm{RM})$ grains in the fluvio-aeolian unit is a result of successive redeposition of sediments by aeolian processes within the valleys and washing away by episodic flows. Material from outside the valley was of minor significance. The beginning of deposition of this unit was diachronic and dependent of local hydrological conditions and lithology of the substratum, or the size of a drainage basin.

- The disappearance of permafrost contributed to a rapid increase in the permeability of the substratum, the disappearance of regular flows and the release of a large amount of sandy material. The rate of permafrost degradation was determined by local factors, mainly by exposure of slopes. This resulted in the rapid disappearance of permafrost at Józefów and, in part, at Niwiska. In contrast, permafrost at Postolin and Berezno lasted until the early Bölling warming phase.

- Despite the diachroneity of the fluvio-aeolian unit and a varying rate of permafrost degrada- tion, there is a marked homogeneity of structural and textural characteristics of deposits. In this case, local factors were of minor importance.

- The aeolian unit was laid down in periods of climatic cooling in the Older and Younger Dryas. These relatively short intervals (several hundred years) resulted in a higher content of EM/RM grains. However, the period was too short to result in stronger processing of quartz grains and an increase in the number of RM grains in relation to the underlying units. The material comes mainly from outside the depositional areas. The lower units were at least partially protected by soil horizons that developed during the Bölling interphase (Józefów and Berezno).

- Compared to other units, the aeolian unit is characterised by the highest heterogeneity of lithofacies and morphoscopic properties of quartz grains. This reflects a stronger impact of local factors (sediment sources, terrain morphology, presence of vegetation cover) on the processing of quartz grains in comparison to climatic, in particular aerodynamic, conditions.

\section{Acknowledgements}

This research was supported by grants N 306197639 and N 306034639 from the Polish Ministry of Science and Higher Education, and continued under the statutory research funds of the Faculty of Earth Sciences and Land Management of Maria Curie Skłodowska University, Lublin, Poland. We are grateful to anonymous reviewers for their critical reviews and constructive comments, which improved the quality of the manuscript.

\section{References}

Cailleux, A., 1942. Les actions éoliennes périglaciaires en Europe. Mémoires de la Société Géologique de France 41, 1-176.

Dylik J., 1969. L'action du vent pendant le dernier âge froid sur le territoire de la Pologne Centrale. Biuletyn Peryglacjalny 20, 29-44.

Dzierżek, J. \& Stańczuk, D., 2006. Record and palaeogeographical implications of Pleistocene periglacial processes in the Drohiczyn Plateau, Podlasie Lowland (Eastern Poland). Geological Quarterly 50, 219-228.

Fedorowicz, S., 2006. Methodological aspects of luminescence dating of Central Europe's Neopleistocene deposits. Gdańsk University Press, Gdańsk, 156 pp.

Good, T.R. \& Bryant, I.D., 1985. Fluvio-aeolian sedimentation - an example from Banks Island, N.W.T., Canada. Geografiska Annaler 67A, 33-46.

Goździk, J., 1980. Zastosowanie morfoskopii i graniformametrii do badań osadów w kopalni węgla brunatnego 'Bełchatów' [Application of morphoscopy and 
graniformometry for investigations of deposits in the 'Bełchatów' brown coal mine]. Studia Regionalne 4, 101-114.

Goździk, J., 1995. Wybrane metody analizy kształtu ziarn piasku dla celów paleogeograficznych i stratygraficznych [Selected methods of the analysis of the sand grain shapes for paleogeographic and stratigraphic purposes]. [In:] E. Mycielska-Dowgiałło, J. Rutkowski, (Eds): Metody badań osadów czwartorzędowych. Wybrane metody i interpretacja wyników [Investigations of Quaternary sediments. Some methods and interpretation of the results]. Warsaw University, Warszawa, 115-132.

Goździk, J., 2007. The Vistulian aeolian succession in central Poland. Sedimentary Geology 193, 211-220.

Huijzer, B. \& Vandenberghe, J., 1998. Climatic reconstruction of the Weichselian Pleniglacial in northwestern and central Europe. Journal Quaternary Science 13, 391-417.

Isarin, R.F.B., Renssen, H. \& Koster, E.A., 1997. Surface wind climate during the Younger Dryas in Europe as inferred from aeolian records and model simulations. Palaeogeography, Palaeoclimatology, Palaeoecology 134, 127-148.

Kalińska, E., 2010. Rozwój piaszczystych osadów form stożkopodobnych na Nizinie Mazowieckiej w młodszym plejstocenie [The development of sandy sediments from cone forms in Younger Pleistocene in the Mazowsze Lowland]. Materiaty Młodych Badaczy, Silesia 2010, 1-8.

Kasse, C., 1997. Cold-Climate Aeolian Sand-Sheet Formation in North-Western Europe (c. 14-12.4 ka); a response to Permafrost Degradation and Increased Aridity. Permafrost and Periglacial Processes 8, 295-311.

Kasse, C., 2002. Sandy aeolian deposits and their relation to climate during the Last Glacial Maximum and Lateglacial in northwest and central Europe. Progress in Physical Geography 26, 507-532.

Kasse, C. \& Vandenberghe, J., 1998. Topographic and Drainage Control on Weichselian Ice-Wedge and Sand-Wedge Formation, Vennebruegge, GermanDutch Border. Permafrost and Periglacial Processes 9, 95-106.

Kasse, C., Vandenberghe, J., van Huissteden, J., Bohncke, S.J.P. \& Bos, J.A.A., 2003. Sensitivity of Weichselian fluvial systems to climate change (Nochten mine, eastern Germany). Quaternary Science Review 22, 21412156.

Kasse, C., Vanderberghe, D., De Corte, F. \& van den Haute, P., 2007. Late Weichselian fluvio-aeolian sands and coversands of the type locality Grubbenvorst (souther Netherlands): sedimentary environments, climate record and age. Journal of Quaternary Science 22, 695-708.

Klatkowa, H., 1996. Uwagi o relacji między seriami eolicznymi a ich podłożem w środkowej Polsce [Remarks about the relationship between aeolian series and their bedrocks in Central Poland]. [In:] Wspótczesne oraz kopalne zjawiska i formy eoliczne, wybrane zagadnienia [The modern and fossil aeolian phenomena and forms, selected issues]. Sosnowiec, 65-75 (in Polish).
Kolstrup, E., 1980. Climate and stratigraphy in Northwestern Europe between 30,000 B.P. and 20,000 B.P., with special reference to The Netherlands. Mededelingen van de Rijks Geologische Dienst 32-15, 181-253.

Koster, E.A., 1988. Ancient and modern cold-climate aeolian sand deposition: a review. Journal of Quaternary Science 3, 69-83.

Koster, E.A., 1995. Progress in cold-climate aeolian research. Quaestiones Geographicae Special Issue 4, 155163.

Koster, E.A., 2009. The history of Late Holocene drift sands in the Netherlands: origin and reactivation. [In:] R. Dulias, J. Pełka-Gościniak \& O. Rahmonova (Eds): Ekosystemy piaszczyste i człowiek. Prace Wydziału Nauk o Ziemi Uniwersytetu Ślaskiego 58, 111-134.

Kozarski, S. \& Nowaczyk, B., 1991. Lithofacies variation and chronostratigraphy of Late Vistulian and Holocene aeolian phenomena in northwestern Poland. Zeitschrift für Geomorphologie N.F., Supplementband 90, 107-122.

Krumbein, W.C., 1941. Measurement and geological significance of shape and roundness of sedimentary particles. Journal of Sedimentary Petrology 11, 64-72.

Kurkowski, S., 1997. Szczegótowa mapa geologiczna Polski w skali 1:50 000, ark. Józefów [Detailed Geological Map of Poland, 1:50,000, sheet Józefów]. PIG, Warszawa (in Polish).

Marks, L., 2002. Last Glacial Maximum in Poland. Quaternary Science Reviews 21, 103-110.

Marks, L., Gałązka, D., Krzymińska, J., Nita, M., Stachowicz-Rybka, R., Witkowski, A., Woronko, B. \& Dobosz, S., 2014. Sea transgressions during Eemian in northern Poland; a high resolution proxy record from the type section at Cierpięta. Quaternary International 328-329, 45-59.

Mądry, S., 1994. Szczegótowa mapa geologiczna Polski w skali 1:50 000, ark. Cmolas [Detailed Geological Map of Poland, 1:50,000, sheet Cmolas]. PIG, Warszawa (in Polish).

McKenna-Neuman, C., 1990. Role of sublimation in particle supply for aeolian transport in cold environments. Geografiska Annaler 72A, 329-335.

McKenna-Neuman, C., 1993. A review of aeolian transport processes in cold environments. Progress in Physical Geography 17, 137-155.

McKenna-Neuman, C., 2004. Effects of temperature and humidity upon the transport of sedimentary particles by wind. Sedimentology, 51, 1-17.

Mol, J., Vandenberghe, J. \& Kasse, C., 2000. River response to variations of periglacial climate in mid-latitude Europe. Geomorphology 33, 131-148.

Molodkow, A. \& Bitinas, A., 2006. Sedimentary record and luminescence chronology of Lateglacial and Holocene Aeolian sediments in Lithuania. Boreas 35: 244-254.

Mycielska-Dowgiałło, E., 1993. Estimates of Late Glacial and Holocene aeolian activity in Belgium, Poland and Sweden. Boreas 22, 165-170.

Mycielska-Dowgiałło, E., 2001. Wpływ warunków klimatycznych na cechy strukturalne i tekstualne osadów mineralnych [Influence of climatic condition on the structural and textural features of mineral deposits]. 
[In:] A. Karczewski \& Z. Zwoliński (Eds): Funkcjonowanie geosystemów w zróżnicowanych warunkach morfoklimatycznych - monitoring, ochrona, edukacja [The functioning of geosystems under different morphoclimatic conditions - monitoring, protection, education]. Poznań, 377-394.

Mycielska-Dowgiałło, E. \& Woronko, B., 1998. Analiza obtoczenia i zmatowienia powierzchni ziarn kwarcowych frakcji piaszczystej i jej wartość interpretacyjna [Rounding and frosting analysis of the sand quartz grains surface and its interpretative value]. Przeglad Geologiczny 46, 1275-1281.

Mycielska-Dowgiałło, E. \& Woronko, B., 2004. The degree of aeolization of Quaternary deposits in Poland as a tool for stratigraphic interpretation. Sedimentary Geology 168, 149-163.

Pye, K. \& Tsoar, H., 1990. Aeolian Sand and Sand Dunes. Unwin Hyman, London, 396 pp.

Ruegg, G.H.J., 1983. Periglacial eolian evenly laminated sandy deposits in the Late Pleistocene of NW Europe, a facies unrecorded in modern sedimentological handbooks. [In:] M.E. Brookfield \& T.S. Ahlbrandt (Eds): Eolian sediments and processes. Developments in Sedimentology 38, 455-482.

Schokker, J., Cleveringa, P., Murray, A., Wallinga, J. \& Westerhoff, W.E., 2005. An OSL dated Middle and Late Quaternary sedimentary record in the Roer Valley Graben (southeastern Netherlands). Quaternary Science Reviews 24, 2243-2264.

Sidorchuk, A., Borisova, O. \& Panin, A., 2001. Fluvial response to the Late Valdai/Holocene environmental change on the East European Plain. Global and Planetary Change 28(1-4), 303-318.

Tsoar, H., 1982. Internal structure and surface geometry of longitudinal (seif) dunes. Journal of Sedimentary Petrology 52, 0823-0831.

Turkowska, K., 1994. La morphogenèse périglaciaire dans les vallées fluviales du Plateau de Łódź et sa différenciation dans le temps et dans l'espace. Biuletyn Peryglacjalny 33, 153-164

Vandenberghe, J., 1988. Cryoturbations. [In:] M.J. Clark (Ed.): Advances in Periglacial Geomorphology. Wiley, 179-200.

van Huissteden, J. \& Kasse, C., 2001. Detection of rapid climate change in Last Glacial fluvial successions in The Netherlands. Global and Planetary Change 28, 319339.

van Huissteden, J. \& Pollard, D., 2003. Oxygen isotope stage 3 fluvial and eolian successions in Europe compared with climate model results. Quaternary Research 59, 223-233.

van Huissteden, J., Vandenberghe, J., van der Hammen, T. \& Laan, W., 2000. Fluvial and aeolian interaction under permafrost condition: Weichselian Late Pleniglacial, Twente, eastern Netherlandes. Catena 40, 307-321.

Winnicka G., 2007. Szczegółowa mapa geologiczna Polski w skali 1:50 000, ark. Czeszów [Detailed Geological Map of Poland, 1:50,000, sheet Czeszów]. PIG, Warszawa (in Polish).
Winnicka G., 2008. Objaśnienia do Szczegótowej mapy geologicznej Polski w skali 1:50 000, ark. Czeszów [Explanations for Detailed Geological Map of Poland, 1:50,000, sheet Czeszów]. PIG, Warszawa (in Polish).

Woronko, B., 2001. Znaczenie analizy obtoczenia i zmatowienia powierzchni ziarn kwarcu frakcji piaszczystej w interpretacji genetycznej osadów czwartorzędowych [The importance of the analysis of roundness and surface matt of sand quartz grains in the interpretation of the origin of Quaternary deposits]. [In:] E. Mycielska-Dowgiałło (Ed.), Eolizacja osadów jako wskaźnik stratygraficzny czwartorzędu [The aeolisation of sediments as an indicator of the Quaternary stratigraphy]. Warszawa, 33-38 (in Polish).

Woronko, B., 2012. Zapis procesów eolicznych w osadach piaszczystych na wybranych obszarach Polski środkowej $i$ pótnocno-wschodniej. [Records of aeolian processes in the Pleistocene sandy sediments in selected areas of central and north-eastern Poland]. Warsaw University Press, Warszawa, 134 pp.

Woronko, B., Rychel, J., Karasiewicz, M.T., Ber, A., Krzywicki, T., Marks, L. \& Pochocka-Szwarc, K., 2013. Heavy and light minerals as a tool for reconstructing depositional environments: an example from the Jałówka site (northern Podlasie region, NE Poland). Geologos 19, 1-2, 47-66.

Zeeberg, J.J., 1998. The European sand belt in eastern Europe - and comparison of Late Glacial dune orientation with GCM simulation results. Boreas 27, 127-139.

Zieliński, P., Fedorowicz, S. \& Zaleski, I., 2009. Sedimentary succession in Berezno in the Volhynia Polesie (Ukraine) as an example of depositional environment changes in the periglacial zone at the turn of the Vistulian and the Holocene. Geologija 51, 97-108.

Zieliński, P., Sokołowski, R.J., Fedorowicz, S. \& Jankowski, M., 2011. Stratigraphic position of fluvial and aeolian deposits in the Żabinko site (W Poland) based on TL dating. Geochronometria 38, 64-71.

Zieliński, P., Sokołowski, R.J., Fedorowicz, S. \& Zaleski, I., 2014a. Periglacial structures within fluvio-aeolian successions of the end of the Last Glaciation - examples from SE Poland and NW Ukraine. Boreas, 43, 712-721.

Zieliński, P., Sokołowski, R.J., Woronko, B., Jankowski, M., Fedorowicz, S., Zaleski, I., Molodkov, A. \& Weckwerth, P., 2014b. The depositional conditions of the fluvio-aeolian succession during the last climate minimum based on the examples from Poland and NW Ukraine. Quaternary International (http://dx.doi. org/10.1016/j.quaint.2014.08.013).

Zieliński, T., 2007. The Pleistocene climate-controlled fluvial sedimentary record in the Bełchatów mine (central Poland). Sedimentary Geology 193, 203-209.

Zieliński, T. \& Pisarska-Jamroży, M., 2012. Jakie cechy litologiczne osadów warto kodować, a jakie nie? [Which features of deposits should be included in a code and which not?]. Przeglad Geologiczny 60, 387-397.

Manuscript submitted 7 January 2015 Revision accepted 15 May 2015 